\title{
ПРЕПОРОД НАЦИОНАЛНОГ КАРАКТЕРА У ЕСЕЈИМА ИСИДОРЕ СЕКУЛИЋ
}

\begin{abstract}
У раду се испитује могућност формирања националног карактера на основу података које Исидора Секулић пружа у својим есејима. Иако се ауторка не користи савременим теоријама, анализом њеног дела открива се да многе појаве на које она указује играју кључну улогу у савременим теоријама нације. На тај начин се долази до закључка да Исидора Секулић јасно одређује идеални и реални тип српске нације, као и да њени есеји посвећени овом питању пре свега имају задатак да позову на културни и национални препород.
\end{abstract}

Кључне речи: Исидора Секулић, есеј, национални карактер, национално, идеални карактер, реални карактер.

Када је Јован Скерлић 1913. године објавио критику поводом „Сапутника”, Исидора Секулић је у историји српске књижевности одређена као писац доброг стила, али слабог уметничког надахнућа. Иако сам признаје да је поменуту књигу читао у ратним условима, критичар допушта да „њена егзотична књига долази у тако незгодан час, најмање погодан за све књиге те врсте” (Скерлић 1971: 401), али, упркос томе, остаје при ставу да „никада у свом животу као тад нисам толико осетио бедну празнину речи и сву таштину књишке литературе” (Исто: 402), као и да сама књига садржи „неврастичарске кризе, обртања и превртања једног малог ја, и артистичко распоређивање паучине фраза" (Исто: 401). Осудити Исидору Секулић као писца који не препознаје историјски тренутак у коме се налази, већ да је њена литература егоцентрична, те да не схвата да „нико на свету није тако занимљив да на двеста страна прича само о себи и да седамнаест страна ситног текста посвети једној својој главобољи" (Исто: 398), чини се неоправданим када се сагледа есејистички опус ауторке, који је већ у том тренутку имао дела са значајним освртом на национално питање.

*tamara.ljujic@gmail.com 
Ипак, да Скерлић није у потпуности погрешио у својој оцени ауторкиног дела говори и суд да се „Гђица Секулић боље чита у одломцима” (Исто: 398). Са овим ставом слаже се и Јован Христић када говори о њеним есејима: „писац без правог средишта који је писао о свему о чему је требало писати, али који је некако остао без текстова које је само он могао написати" (Христић 2005: 118). Уколико је писац писао о свему о чему је требало писати, као му се онда може замерити што није писао о ономе о чему није ни требало писати?

Да је ауторка добар есејиста, Христић не доводи у питање: „Исидора Секулић је, највише од свега, наш велики есејист" (Исто: 118). Њени есеји поседују све особине доброг есеја: „наглашен субјективни став и особени стил, неопходну ерудицију, свестрану културу и специфичан таленат" (РКТ 1992: 188). Ипак, када се зађе у детаљније проучавање њених есеја и савлада почетна занесеност коју буде текстови, који су „на граници критичке имагинативне прозе, час анализа, а час висока литерарна евокација живота” (Христић 2005: 119), долази се до закључка да су они „,стално писани у повишеном тону, с многим инверзијама и с бескрајним варијацијама једне идеје, једног мотива, па чак и једне фразе” (Јеремић 1972: 294) или да „њена импресионистичка запажања и уопштене одреднице не пружају никакво стварно објашњење духовног стваралаштва у једној националној средини".

Број тема у есејима Исидоре Секулић је велики, а узрок томе Христић проналази у чињеници да она „износи чињенице које претпоставља да културан човек или културна младеж треба да зна" (Христић 2005: 120-121). О идејама националног и космополитског у есејима Исидоре Секулић писала je Владислава Рибникар. У њеном раду, због наглашености на односу национално - космополитско, преиспитује се да ли истицање специфичности националних вредности нарушавају космополитске вредности. Драган Јеремић примећује да је „она својом широком културом важила за амбасадора космополитизма у нашој средини, а била је у ствари пропагатор наших националних ставова као универзалних вредности” (Јеремић 1972: 302). Ипак, чини се да терминолошка неодређеност госпође Секулић у есејима који су посвећени националним питањима је утицала и на истраживаче, те су они, налик на жанр који проучавају избегли стручно утемељење кад пишу о њима.

Временски период у оквиру којег ауторка писала есеје посвећене српској нацији и њеним различитим облицима постојања обухвата преко педесет година стваралаштва. Највише текстова написала је у периоду од 1911. до 1913, што се објашњава утиском који су на ауторку оставили балкански ратови. Због историјског тренутка у коме ствара, мора се утврдити о чијем националном карактеру ауторка говори. У есејима се помињу и југословенство и српство, али се може сматрати да, осим када експлицитно не казује, госпођа Секулић пише о српском националном карактеру. У есеју „Ми и стварност” она говори о Југословенима као о народу који у стварност не верује и стварност не воли. Ипак, када пише о Србима и Хрватима, она пише о браћи, не о једном народу који би био Ми и као такав целовит, већ о нама (Ми) и њима (Они), који се не могу посматрати као целина, односно један народ. 
Жарко Требјешанин у „Речнику психологије” национални карактер одређује као „етнопсихолошки конструкт који означава сложај црта карактера и образаца понашања, типичних на једну нацију” (Требјешанин 2008: 289). Када говори о цртама српског карактера, Исидора, иако није могла познавати модерне теорије и схватања, јасно у начину на који пише одређује оно што Требјешанин именује као иделани и реални карактер нације: „у описивању националног карактера често постоји мешање идеалног (какав би требало да буде припадник неког народа према мерилима његове културе) и реалног (какви су заиста припадници неке нације)" (Требјешанин 2008: 289). Чини се да ниједан од мислилаца који су се бавили овим питањем (Вук Караџић, Владимир Карић, Јован Цвијић, Душан Недељковић, Герхад Геземан, Владимир Дворниковић, Драгиша Васић и др.), иако су указивали на позитивне и негативне стране српског националног карактера, нису направили такву разлику какву је направила госпођа Секулић. Разлог за такав приступ проблему налази се у намери са којом је писала есеје - док су остали описивали и дефинисали реалне особине српског националног типа, она пружа идеал ка коме би се нација морала усмерити.

Говорити о идеалном националном типу значи открити пред читаоцима и сопствени систем вредности, као и однос који аутор има према савремености. Госпођа Секулић има јасан став према вредности коју прошлост има: „ишарана јадом и чемером, али зато славом и јунаштвом поноснога Србина” (Секулић 2001: 13). Она говори о пољу као залогу врлине и једном потврђене народне части. Косовска легенда игра важну улогу на народној прошлости, те се са Светим Савом одређује као „вертикала српске историје” (Самарџић 1990: 65). Ипак, госпођа Секулић, када говори о прошлости, не позива се на истакнуте историјске личности иако „култ хероја представља један од најбитнијих елемената идеологије сваке организоване људске заједнице” (Макуљевић 2006: 256). Насупрот томе, истиче да „Ми нисмо само потомци Душана и Марка, ми смо деца голог и непросвећеног народа, који се због друштвеног мрака грехом и дивљаштвом кола" (Секулић 2001: 21-22), те Србе одређује као „бедну рају”. Ауторка на овај начин покушава да превреднује епску прошлост српског народа - јунаштво више не припада истакнутим појединцима, већ обичном човеку, чиме се премошћава генерацијски јаз између оних који су били и оних који јесу. На овај начин ауторка се надовезује на традицију оних националиста који су се „позивали на древна херојска времена као неку врсту лучоноша за модерни национализам" (Велер 2002: 41). Став ауторке о развоју националне свести код Срба је доследан, једино што варира јесте тренутак у коме се треба формирати нови национални тип. У есеју „Културни национализам” госпођа Секулић каже да:

У својим политичким и културним невољама, ми смо своме национализму давали најразноврсније одлике. Имали смо уски шовинизам, пун епског певања и запевавања, пун ситних жеља, и пун немоћних претња и ишчекивања. Имали смо у последње време, нарочито пред рат, проповедање пусте, бруталне силе, што је, уосталом, као ad hoc додатак суштини нашег национализма, било сасвим на свом месту (Секулић 2001: 57). 
Она већ у првим есејима из 1912. позива на промену промене, али ратови који испуњавају прву половину двадесетог века утичу на њено мишљење о времену када до препорода треба доћи, те у неким есејима већ каже да се са њим касни, а у неким да на њега треба причекати.

Идеални карактер српске нације мора као водеће вредности прихватити следеће:

[...] мирнодопски, нормални, мирни активни национализам [...], тај национализам треба да је и по суштини и по облику чиста, висока култура. Култура у најбољем смислу речи. Морал, хуманизам, етика, честитост. Ваљаност и честитост и првокласност не само српска, него и човечанска (Секулић 2001: 59).

У овом ставу проналазимо проблем на који је указао и Слободан Јовановић - недостатак културног обрасца код Срба. И госпођа Секулић, као и Јовановић, у промени на пољу културе виде начин за промену у области идеје национализма. Јовановић каже да аутостереотипи утичу на начин на који нација себе доживљава, те је потребно да сама нација промени схватање о себи. У својој књизи Политичке и правне теорије Драгица Вујадиновић Милинковић запажа да „нигде се грађани не потчињавају тако безусловно државној идеји као на фронту” (1996: 345). Ова, како је Исидора Секулић назива, ратна реторика, представља екстреман вид неопходан за очување надахнућа у борби, али не може бити модел по коме ће наставити са очувањем нације. У таквој средини идентитет народа се дефинише у разлици од другог, обележавањем непријатеља, и док су то некада били Турци, ауторка савременог непријатеља проналази у „мађарској чизми и аустријској камџији” (Cекулић 2001: 38). Ипак, да се нација не би формирала само на основу разлике од другог, ауторка инсистира на просвећености народа, да би „кад војници, по свршеном послу поскидају оружје, и, осим војничког, имају свој грађански понос и своју индивидуалну амбицију" јер само је културан човек, без емоција и без сцена, у свако доба родољуб и националац" (Исто: 68). Јасно је да она сматра да механизам по коме долази до промене у националном карактеру јесте да се прво промени аутостереотип, а онда ће народ почети да се понаша у складу са оним што о себи мисли.

Упркос постојању јасних вредности које треба неговати, госпођа Секулић примећује да ће до жељене промене у националном карактеру тешко доћи јер „Ми немамо ниједне модерне велике идеје” (Исто: 20). Она оштро критикује недостатак културне политике, јер „сав наш културни прогрес је без оца и мајке” (Исто: 31), а припадници нашег народа су „сањала и неплодне бунџије” (Исто: 23). Промена се мора испровоцирати јер:

Ми немамо времена да чекамо и рачунамо на природно сазревање генерација; ми морамо у свим живим генерацијама и сваковрсним оруђем одједаред и бранити и гради$m и$. Школа међу децом, а свесна и поштена интелигенција међу народом, мора проповедати тај нови модел перманента рада без одмора (Исто: 25).

Инсистирање на постојању јасне културне политике и њене заступљености у образовању Исидору Секулић приближава Гелеровом схватању нације: 
$[\ldots]$,границе културе у оквиру које су образовани истовремено су и границе света у оквиру којег они могу, морално и професионално, дисати. Човеково образовање је његова далеко најдрагоценија инвестиција и у ствари му даје идентитет. Модерни човек није лојалан ни монарху, ни земљи, ни вери, ма шта говорили, већ култури (1997: 57).

Иако својим истраживањем Гелер не припада генерацији госпође Секулић, њихови ставови су веома блиски. Гелеров поглед на нацију је модернији јер не вреднује старозаветне елементе које Исидора Секулић задржава. Ханс Урлих-Велер у студији „Национализам: историја - форме - последице” говори о старозаветним елементима који су постали саставни део националне идеологије, а то су идеја о изабраном народу, обећана и света земља, постојање смртног непријатеља и историјска мисија. Ауторка је, како је претходно речено, сматрала да смртни непријатељ српског народа увек постоји, а која нација ће бити супротстављена српској зависи од историјског тренутка у коме се овакав непријатељ тражи. Као обећана и света земља може се идентификовати Косово, али само ако престане да се сагледава као део прошлости, већ постане инспирација у будућности. Она прецизно одређује Косово као обећану и свету материнску земљу српског народа у свом есеју о Кочићу: „Косово живи и живеће и сутра и прекосутра, иако увек као нешто друго и треће, политичко, културно, уметничко, научно. Косово које је све већа и већа сума истина с којима се ми држимо и у нечем битном не мењамо" (Cекулић 1971: 68).

Да би дошло до потребног препорода, ауторка мора потврдити да у народу постоји витална снага која ће омогућити напредак. У есеју „Шта су Србину гусле”, она описује лик Србина:

немоћан је - у бурно доба младости његове те су ноге прешле највише врлети, најопасније стене, вребајући можда само једног Турчина; те су ноге канда хајдука горског носиле. Тело му је изнурено јер су силне ране исцедиле крв његову, разрушиле му здравље, али му души и храбром срцу нахудити не могоше. Седе власти - које поветарац у сребрне таласе разигравао - покривају му старачку главу, преко које су многи суморни дани прелетали; али му покривају и поносно чело, као да би хтеле сакрити она два празна ока, која много приповедају, мада у њима нема покрета, нема живота, јер седи старац је - слеп. [...] Он је дакле изнурен болесник, он је слеп, па ипак му још сува рука није малаксала. А како би? Та је рука некад а младалачком снагом неописано вешто крстарила по редовима непријатељским, а сад да престане" (Секулић 2001: 16).

Да би повратили некадашњу славу, Срби се морају окренути непромењивом делу националног карактера, а за ауторку су то икона, мач и гусле. Кључно за њу у овој групи јесу гусле, ,то оружје, та икона, та светиња народа" зато што су оне „пуне морала, истине, правде и других врлина, будио у народну заспалу клицу храбрости" (Исто: 16). Овим се показује да госпођа Секулић не жели да одбаци или уништи ни на који начин српску традицију. Њен позив за препород је само позив да се нација прилагоди новим историјским околностима, а да истовремено очува свој идентитет.

Да би се говорило и реалном српском националном карактеру код Исидоре Секулић, мора се претходно поставити питање зашто га ауторка одбацује. Она ниједном у преко двадесет есеја не даје могућност да српска нација може опстати уколико се њен карактер не прилагоди, па ипак не доводи у 
питање могућност да нација, неспремна да се прилагоди, нестане: „Да пропаднемо? За нас је и то сувише рано јер и пропасти вреди само онда ако ће се пропасти као Гранада и Троја" (Секулић 2001: 32). Госпођа Секулић у есеју „Како је управо било” говори о начину на који се различити народи изборе са несрећама које су пред њима:

[...] народи, који у несрећи проживљују задње дане своје, пролазе кроз несрећу с највишим својим квалитетима; народи пак, којима је несрећа намењена па се кроз њу тек роде или развију, преживљују и савлађују несрећу најнижим својим квалитетима просте виталност (Исто: 71).

На основу есеја јасно је да ауторка као доба задюих дана види Косовски бој и његову суштинску улогу у српској традицији зато што у времену искушења које је наступило након њега српски народ је задобио и метафизичку раван. Највеће искушење српског народа није довело до нестанка, већ је учврстило идентитет народа. Пошто после Косовског боја није било тако великог страдања српског народа (из перспективе ауторке), Срби немају морално право да нестану пред много мањим искушењима. Ауторка оштро осуђује понашање народа за време аустријске владе у земљи, јер савремено доба је донело јачање индивидуалности, и нестанак вредности које су за њу кључне, као што су јунаштво и част. Исидора Секулић зато одбацује савременост: „Такозвана „савременост”, од које су социолози и друштво начинили божанство, не ваља ни пару” (Исто: 81). Ако се прихвати да „несавремен човек заузима став против савремености: док анахрон човек постоји мимо времена, дотле се насавремен човек ситуира унутар времена" (Ломпар 2016: 17), онда се Исидора Секулић јавља као интелектуалац који јасно бира несавременост, јер не може прихватити афирмисане вредности друштва у коме живи. Ситуација је супротна са српском нацијом, која би се у том случају открила као анахрона, прилагођена времену страдања и ратне реторике, али не савременом грађанском друштву. Зато се као главне мане реалног карактера истиче „да смо солидарнији у оном што мрзимо него у оном што волимо” (Секулић 2001: 37), да је највећа мана нације „несретна неслога Србинова” (Исто: 15), као и да „наша национална свест није цивилизована, да је проста, уска, сељачка свест с грамзивим, гладним моралом оних који нису сасвим свесни шта је боље, и нису сасвим свесни да су бољи" (Исто: 60).

Само постојање реалног и идеалног карактера, иако их ауторка на тај начин не именује, показују да се ови есеји могу одредити као идеолошка основа за препород идеје српске нације. У том препороду тежило би се прилагођавању савременом добу и грађанском друштву. Није далеко Исидора Секулић у овом захтеву од Слободана Јовановића, који тежи да замени полуинтелектулаце правим интелектуалцима. Стога, чини се да госпођа Секулић није погрешила бирајући теме за своје есеје, она је писала баш о ономе о чему је требало писати на почетку 20. века, а то је очување идентитета српске нације у времену великих промена. Потпуно се мора одбацити Скерлићев прекор госпођи Секулић да није осећала историјски тренутак и патње српског народа. Она је отишла и корак даље и дала пут којим би се српска нација морала кретати у будућности. 


\section{ЛИТЕРАТУРА}

Велер 2002: Х.У. Велер, Национализам: историја - форме - последице, Нови Сад: Светови.

Вујадиновић Милинковић 1996: Д. Вујадиновић-Милинковић, Политичке $и$ правне теорије, Београд: Правни факултет Универзитета у Београду.

Гелер 1997: Е. Гелер, Нације и национализми, Нови Сад: Матица српска.

Јеремић 1972: Д. Јеремић, Исидора Секулић есејиста, у: Кьижевна критика, Београд: Нолит, 293-303.

Ломпар 2016: М. Ломпар, Похвала несавремености: есеј, Београд: Лагуна. Макуљевић 2006: Н. Макуљевић, Уметност и наџионална идеја у XIX веку, Београд: Завод за уџбенике и наставна средства.

РКТ: Rečnik književnih termina, Д. Живковић (ур.), Београд: Нолит.

Самарџић 1990: Р. Самарџић, Косовско опредељење; историјски огледи, Београд: Српска књижевна задруга.

Секулић 1971: И. Секулић, Огледи и записи, Нови Сад: Матица српска, Београд: CK3.

Секулић 2001: И. Секулић, Записи о моме народу, Београд: Stylos.

Скерлић 1971: Ј. Скерлић, Критике, Београд: Српски књижевни гласник; Нови Сад: Матица српска.

Требјешанин 2008: Ж. Требјешанин, Речник психологије, Београд: Стубови културе.

Христић 2005: Ј. Скерлић, Изабрани есеји, Београд: Српски ПЕН центар.

Tamara M. Ljujić

REVIVAL OF NATIONAL CHARACTER IN THE ESSAYS BY ISIDORA SEKULIĆ

(Summary)

The paper examines the possibility of forming a national character based on the information Isidora Sekulić offers in her essays. Although the author does not use modern theories, analysis of her work revealed that many of the events which she points out play the key role in modern theories of the nation. This way leads to the conclusion that Isidora Sekulic clearly defines the ideal and the real tipe Serbian nation, and that her essays devoted to this issue are primarily tasked to hold cultural and national revival. 